\title{
The Association of Knowledge Management, Organization Culture, and Innovation With Organizational Performance: A Case At Study Institute Research Xyz
}

\author{
Navik Puryantini ${ }^{1^{*}}$, Rofikotul A. ${ }^{2}$, Dian Shinta P. ${ }^{3}$, and Bambang Tjahjadi ${ }^{4}$ \\ ${ }^{1}$ Laboratory for Hydrodynamics Technology, Agency for Assessment and Application of Technology, \\ Surabaya, INDONESIA \\ 2,3,4 Faculty of Economics and Business Airlangga University, Surabaya, INDONESIA \\ *Corresponding author; Email: navik.puryantini@gmail.com
}

\begin{abstract}
The purpose of this study is to analyze the impact of innovation as the mediation variable towards the knowledge management relationship and also culture organization towards organization performance. The population in this study are employees of XYZ. The data collection in this study is conducted by using the questionnaire and then the data is analyzed with Partial Least Squares method. The results show that; (1) knowledge management has the influence on innovation; (2) The effect on the organizational culture of innovation; (3) Knowledge Management of an effect on the performance of the organization; (4) The organizational culture influence on organizational performance (5) innovation does not affect the performance of the organization, (6) the innovation did not mediate the relationship of knowledge management to organizational performance; (5) innovation does not mediate the relationship of organizational culture on organizational performance. There is an explanation obtained from the interview that describe the gap and difference perception between innovation authority and power. Thus, the innovation always depends on the individual who has willingness to make the innovation.
\end{abstract}

Keywords: Knowledge management; organization culture; innovation; organizational performance.

\section{INTRODUCTION}

Globalization, which is characterized by the emergence of information and communication, is an era that cannot be avoided. Currently, all nations are competing to be in the forefront in the era of competition. Competitiveness becomes the most powerful weapon to win the market competition. Talking about the competition between nations, each nation is required to have high competitiveness, In the midst of the Indonesian nation attempts to stand in line with other nations in the world, the President of the Republic of Indonesia, Joko Widodo has set the technological innovation as one of the pillars of nation building. Technology, as the result of the nation's work, should be able to increase the productivity of the production system, which, in turn, will stimulate higher economic growth and competitiveness of Indonesian nation.

In line with the above efforts, the Institute Research (XYZ) has been repositioned to increase its contribution to the development and use of innovative technology to produce a wide range of innovative products. Innovation is considered as an important mechanism to become more competitive and to survive in the global business world [29]. According to [2] innovation is an important force in improving organizational performance and can promote economic and development growth. Moreover, organizations must not only be innovative to survive and thrive in a competitive environment but also change rapidly. Therefore, the success of creating innovation is an important thing to be possessed [5]. While in [9] it is explained that innovation may be a new product or service, a new production process technology, new structure and administration systems or a new plan for the organization's members.

Organizations are required to have the good and deep knowledge, to make innovation, so that in the process of knowledge creation, organizations seek to improve its working methods. The innovation process depends a lot on knowledge, mainly because knowledge represents an area (realm) that is much deeper than the data, information and conventional logic; therefore, the power of knowledge lies in subjectivity, which underlies values 
and assumptions that became the foundation for the learning process [23]. Knowledge is the main resource and has an important role in achieving sustainable competitive advantage and performance achievement. As one of the competitive assets, knowledge should be owned by every individual to be able to develop the skills, so that through the mastery of knowledge and skills, individuals can manage their own careers. Therefore, knowledge must be managed through a system of knowledge management.

$\mathrm{XYZ}$ is one of the research institutions that use human capital as a source of knowledge, innovation, and renewal. Research institutions typically rely on the informal communication among individuals and are people-centric operations. This often lead to the spread of knowledge becomes disconnected so that important information cannot be conveyed properly among individuals in these institutions. Therefore, knowledge in $\mathrm{XYZ}$ needs to be managed and documented by using the concept of knowledge management, which is a series of activities that are used by organizations or institutions to identify, create, describe, and distribute knowledge to be reused, known and studied in the organization. This activity is typically associated with an objective of organization and aims to achieve a specific outcome such as shared knowledge, improved performance, competitive advantage, or higher levels of innovation. To support this, the XYZ developed a Knowledge Management System to assist in the management of knowledge in XYZ inaugurated on 2 November 2016.

In order to develop technologies independently, there must be knowledge management, human resources skills and the ability to absorb science and technology in XYZ. The goal of KMS is to provide convenience to XYZ's employees in exploiting, exploring and sharing knowledge so that a process of creativity and technology innovation in XYZ will be pushed wider and every employee quickly improve their competence in the hope to create innovations in XYZ. The difference in information management to knowledge management is that information management focuses on the management of explicit knowledge, while knowledge management focuses on how to capture tacit knowledge to become explicit so that it can be useful and used by others, and it is both difficult and a challenge for XYZ.

One of the critical success in the implementation and development of knowledge management in an organization is a culture. Culture is also a significant factor in the creation and sharing of knowledge with the purpose of improvement of organizational innovation. Knowledge in an organi- zation is the main asset apart from the tangible, in the theory of RBV. The success of an organization depends on knowledge management on facing environmental change. The ability to adapt to environmental changes will improve innovation and organizational performance. [19] say that organizational culture can affect innovation, whether it encourages or inhibits in order to be successful in innovating and adopting technological advances.

According to [5], the sustainable competitive advantage of the organization comes from the peculiarities of this valuable, rare, imperfect and not imitable for the substituted resource. Organizational culture can be a source of competitive advantage if they produce attributes by combining elements of tacit knowledge, social interconnection, and specificity [6]; [40]. Thus, a direct positive relationship between internal integration and performance of the company should be there. The relationship between organizational culture and organizational performance has also been done by [26], [3] and [32] who say that organizational culture has a positive relationship to organizational performance.

Performance is a process used by the leadership to determine if an employee performs work in accordance with the duties and responsibilities or not, so the steps that are used to represent the performance are based on the circumstances of an organization that is being observed. [17] introduces the balanced scorecard that emphasizes on all financial and nonfinancial measures to become part of the information system for workers at all levels in the organization/company.

Research on the relationship of knowledge management has been done in some previous studies. Empirical evidence from [38] research state that a knowledge management strategy directly affects the performance of the organization as well as an indirect effect through innovation as a mediating variable. This research was conducted on mobile telecommunication sector in Iraq. The results of [38] research are supported by [7] study which analyze the relationship of Strategic knowledge management (KM), the company's innovation strategy and organizational performance in 310 Spanish organizations. The results show that both knowledge management strategies (codification and personalization) affect the innovation and organizational performance directly or indirectly. The same study also conducted by [18] which support [38] and [7] research.

Research focuses on sharing knowledge (knowledge sharing) on the ability of innovation and innovation performance [37]. The results of this study indicate that knowledge sharing does 
not affect the ability of innovation and innovation performance. [37] research, supported by [25] research, indicates that knowledge management influence on innovation, but innovation does not have an influence on performance.

[21] stated that innovation is the main factor affecting the success of a company on the competitive market. Research conducted on the relationship of organizational culture, innovation, and organizational performance indicates that organizational culture encourages innovation and company performance. This research is also supported by [16] who also examine the relationship among workplace culture, innovation and organizational performance using Schein's model of organizational culture, the result is that the cultural layers such as norms, artifacts and innovative drive innovation and company performance.

[35] use innovation as a mediator on the relationship between organizational culture and corporate performance. The results of [35] study revealed that in the banking sector, the organizational culture and innovation has a direct and positive effect on the company's performance, but the culture of the organization is found to have no significant regression coefficients on the company's performance with organizational innovation as mediation.

Based on the description above, there is the view of the literature and gap in the results of previous studies. Accordingly, the motivation of this study was to test the effect of knowledge management and organizational culture on innovation and organizational performance. The originality of this research is to combine the influence of knowledge management variables and organizational culture variables on innovation and organizational performance.

Based on the statement above, there are several issues that need to be investigated, which are: (1) How the influence of knowledge management on innovation, (2) How does the impact of organizational culture on innovation, (3) How does the influence of knowledge management on organizational performance, (4) How does the influence of organizational culture on organizational performance, (5) How does the influence of knowledge management to organizational performance mediated innovation, (6) How does the influence of organizational culture on organizational performance mediated innovation.

This study is expected to provide empirical evidence about the effect of knowledge management and organizational culture on organizational performance mediated innovation. Besides, this research is expected to provide guidance for $\mathrm{XYZ}$ in describing the extent on knowledge management and organizational culture on innovation and organizational performance, which can be used as input for XYZ in order to take steps to improve organizational performance.

\section{Theoretical Resource-Based View (Resource- Based Views)}

At the beginning of the decade of the 1990s, there was a change in perspective that put the organization into a closer view of the factors of organizational resources as a Resource-Based View (RBV) competitive advantage. RBV is aimed at presenting the importance of specific organizational resources in achieving a competitive and supportive advantage [24]. The main substance of the resource-based view is a resource that can generate sustainable competitive advantage namely valuable, rare or unique, hard to imitate, and no substitution resource [5] Starting from the strategic management literature, Knowledge-Based View (KBV) built based on this perspective and expand the organization's resource-based view (RBV).

\section{Knowledge management}

Knowledge is increasingly recognized as an important asset of the organization. Knowledge is power the most recent paradigm. In the modern economy, organizations that are utilizing the knowledge is an organization that has a competitive advantage. The competitive advantage is realized through the full utilization of information and aggregated data by utilizing the skills, ideas, commitment, and motivation of employees. The new paradigm today is that knowledge in the organization should be shared (sharing) in order to support the growth and development of the organization [34]. There are two types of knowledge: (1) Implicit Knowledge (tacit) is the knowledge that is still in the minds of individuals who have the knowledge and personal. Thus, it is important for an organization to discover, disseminate and utilize implicit knowledge of each employee in order to optimize the use of their own intellectual capital [23]; (2) Explicit knowledge (explicit) is the explicit knowledge available within the organization. In general, explicit knowledge is structured and reflected in the various references regulations and labor standards in the organization.

The difference between tacit knowledge and explicit knowledge suggests four basic patterns for creating knowledge within the organization [23] (1) Socialization (from tacit to tacit), (2) Externalization (from tacit to explicit), (3) Combination of explicit to explicit and (4) Internalization of explicit 
to tacit. There are many definitions of knowledge management of various researchers. Each of these interpretations is based on professional background and research purposes. This study refers to [15] who argued the main process in knowledge management includes knowledge creation (creation), the use of knowledge (utilization) and knowledge sharing (sharing). Knowledge creation is an activity for creating knowledge. The knowledge is obtained from the information in the form of individual experience and expertise. Knowledge utilization is the activities associated with the application of knowledge in the form of technical devices include machines and equipment used for value-added or productivity. Knowledge sharing involves the transfer of knowledge activities from one party to another party. Sharing knowledge means that each individual is aware of the importance of knowledge to the company and share the knowledge gained with other individuals.

\section{Organizational culture}

Organizational culture is a belief or an agreed value that is meaningful to an individual in the organization used as guidelines or rules of behavior within the organization [11]. Therefore, because the culture of the organization is guidelines/rules of behavior within the organization, organizational culture can affect the performance. [31] define organizational culture is a pattern of beliefs and expectations held by members of the organization.

Cultural organizations also called corporate culture, namely a set of values or norms that have relatively long been applied, are shared by the members of the organization (employees) as norms of behavior in solving the problems of the organization (company). In most organizations, values and practices that are shared (shared) have been growing rapidly along with the times and really affect how an organization is run. Meanwhile, according to [28] organizational culture is a system of shared meaning held by members that distinguish an organization from other organizations.

\section{Organizational Performance}

Performance is a process used by the leadership to determine if an employee performs work in accordance with the duties and responsibilities or not, so the steps that are used to represent the performance are selected based on the organization that is being observed. This study refers to the concept of [15], which introduced the balanced scorecard that emphasizes on all financial and nonfinancial measures to become part of the information system for workers at all levels in the organization/company. The balanced scorecard is structured into four impartial perspectives, namely: 1) financial perspective, 2) customer perspective, 3) internal business process perspective, and 4) learning and growth perspectives.

\section{Relations of Knowledge Management and Innovation}

The innovation process depends a lot on knowledge, mainly because knowledge represents an area (realm) that is much deeper than the data, information and conventional logic; therefore, the power of knowledge lies in subjectivity, which underlies values and assumptions that became the foundation for the learning process [23]. Innovation related to the knowledge that can be used to create products or processes and new services in order to increase competitive advantage and to meet customer needs which are always changing.

\section{Relations of Organizational Culture and Innovation}

[19] say that organizational culture can affect innovation, whether it encourages or inhibits. In order to be successful in innovating and adopting technological advances, companies must be able to meet the requirements in terms of the behavior of internal and external relations at the same time. [1] states that the important thing in strategic management is the difference in performance among companies that compete with each other both product and services and ways to maintain a competitive advantage. Innovation is one of the most important ability to differentiate products and services as a whole to get the superior performance. That is the importance of organizational culture in influencing the innovative and positive influence on organizational performance.

\section{Relations of Knowledge Management and Organizational Performance}

View of the knowledge-based resource is an approach to understand the relationship between organizational capabilities and organizational performance. Knowledge-based resource theory states that knowledge is the most strategic and significant as the company's resources. Knowledge-based resources are usually difficult to be imitated by other organizations and can be used as a source of competitive advantage. Knowledge management has emerged as a source of sustainable competitive advantage [5]. Knowledge management is a management tool that can be used to support the achievement of organizational goals and demonstrate 
the competitive advantage to create better organizational performance [20]. Empirical evidence says that knowledge management capacity, knowledge acquisition, and dissemination are positively related to organizational performance [22].

\section{Relations of Organizational Culture and Organizational Performance}

The sustainable competitive advantage of organizations comes from the peculiarities of this valuable, rare, imperfect and not imitable for substituted resource [5]. Organizational culture can be a source of competitive advantage if they produce attributes by combining elements of tacit knowledge, social interconnection, and specificity [6]; [40]. Internal integration is beneficial to the organization as it can take advantage of a shared vision and shared values among employees and units as well as a strong identification with the organization. Thus, a direct positive relationship between internal integration and performance of the company should be there. The relationship between organizational culture and organizational performance has also been done by [26], [3] and [32] that say that organizational culture has a positive relationship to organizational performance.

\section{Relations of Innovation and Organizational Performance}

[4] research address that there is a significant positive relationship between innovation and business performance. Furthermore [39] provide research support to [4] and this study, [39] use the sample of 159 companies belonging to the family of Istanbul Chamber of Commerce database in the Marmara region, Turkey, that show the result that there is positive influence of innovation or relationship orientation on organizational performance.

\section{Relationship of Knowledge management, Innovation, dan Organizational Performance}

The relationship between KM and innovation, and the relationship between RBV innovations. In theory RBV is said to be known rather than tangible in an organization. The success of an organization depends on deep knowledge management. The ability to adapt to changing environments will enhance innovation and organizational performance. Empirical evidence of [38] states that KMITED's strategy is direct to organizational performance as well as the indirect spirit through innovation as a mediating variable. The study was conducted in the mobile telecommunications sector in Iraq. [7] strategic management techniques (KM), corporate innovation strategies and organizational performance in 310 greek organizations using structural modeling equations The research results show both indirect KM (codification and personalization) strategies (through improvements in innovation capability). The relationship between knowledge management, innovation and performance are also examined by [18] expressing opinions on good and indirect performance.

The research of [37] focuses on knowledge sharing on innovation and innovation performance. The results of this study show that knowledge sharing has no effect on innovation ability and innovation performance. This research is conducted on companies in Turkey. [25] entitled The Effect of Knowledge Management on Innovation, Implementation of Strategy and Organization Performance (Study at Lavalette Malang Hospital) shows that knowledge management influences innovation, but innovation has no effect on performance.

\section{Relations of Organizational Culture, Inno- vation, and Organizational Performance}

The organization's ability to implement the values of organizational culture can contribute to the ability of knowledge transfer within the organization. In the RBV theory said that the success of an organization depends on knowledge management in the face of environmental change. The ability to adapt to changing environments will enhance innovation and organizational performance [5]. Thus, organizational culture is a very important factor as a driver of organizational functions, such as innovation, productivity, and organizational performance.

[21] state that innovation is the main factor affecting the success of a company in a competitive market. Research conducted on the relationship between organizational culture, innovation and organizational performance indicates that organizational culture encourages innovation and corporate performance. The study is also supported by [16] which also examines the relationship between work culture, innovation and organizational performance by using scheins model organization cultivation, the result that cultural layers such as norms, artifacts and innovative drive innovation and company performance.

[35] use innovation as mediating the relationship between organizational culture and corporate performance. The results of [35] revealed that in the banking sector, the organizational culture and innovation has a direct and positive effect on the company's performance, but the culture of the organization is found to have no significant regression coefficient on the company's performance with organizational innovation as mediation. 


\section{Conceptual Framework}

Based on the exposure discussed earlier, the model proposed in this research is as follows:

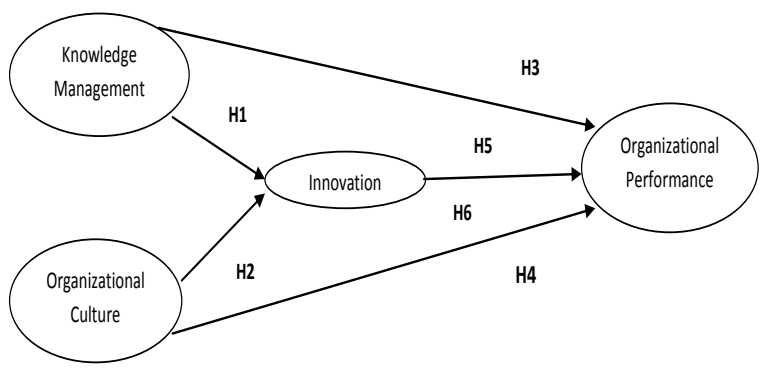

Figure 1. Conceptual Framework

\section{Hypothesis Development and Analytical Model}

This study begins with the framework of thinking process that is doing the theoretical analysis of RBV Theory. The theory is studied because it has relevance to the problems posed in this study. This is done because the theory has a universal nature which means it applies anywhere, anytime and general, but it can be applied to specific cases containing general conclusions to specific conclusions. This plot of thought shows deductive logic.

Empirical studies conducted by studying previous research related to the issues raised in this study. At the time of conducting an empirical study there is a generalization process of things that are specific to the things that are general. This thought flow shows inductive logic. Based on the explanation above, the hypothesis in this study is:

H1: Knowledge management has a direct influence on Innovation

H2: Organizational Culture has a direct influence on Innovation

H3: Knowledge management has a direct influence on Organizational Performance

H4: Organizational Culture has a direct influence on Organizational Performance

H5: Innovation has a direct influence on Organizational Performance

H6: Knowledge management has an influence on Organizational Performance through Innovation

H7: Organizational Culture has an influence on Organizational Performance through Innovation

\section{METHODOLOGY}

The type of research that is conducted is quantitative and qualitative research that is exploratory in order to know the influence of knowledge management, organizational culture to innovation and organizational performance. Sources of research data obtained from primary data and secondary data. Primary data obtained through the tool in the form of questionnaires and interviews with some informants. Secondary data is supporting data related to research problem but this data obtained from resource not directly, for example obtained from publication book and papers of XYZ, literature, research journal.

Knowledge management used in this study uses the concept of [13], which includes the creation of knowledge, the use of knowledge and sharing knowledge with the indicator as follows:

1. Knowledge management: Process-oriented management to create knowledge

2. Knowledge utilization: activities related to the application of knowledge in the form of technical tools such as machinery and equipment used for the increase of added value or productivity

3. Knowledge sharing: concerning the activity of transferring knowledge from one party to another party

The organizational culture based on [27], has 7 primary characteristics that together capture the essence of an organizational culture that is:

a. Innovation and risk-taking, i.e. the extent to which employees are encouraged to be innovative and risk-taking

b. Attention to detail, i.e. the extent to which employees are expected to show precision (accuracy), analysis and attention to details

c. Outcome orientation, i.e. the extent to which management focuses on results rather than on the techniques and processes used to achieve that outcome

d. People orientation, i.e. the extent to which management decisions take into account the effect of results on people within the organization.

e. Team orientation, i.e. the extent to which work activities are organized around teams, rather than individuals

f. Aggressiveness, i.e. the extent to which people are aggressive and competitive rather than casual

g. Stability, i.e. the extent to which the activities of the organization emphasizes maintained the stability of its activities.

In accordance delivered by [10], innovation is an introduction to equipment, systems, laws, products or services, new technology production process, a structure or a new administration, or the new planning program for the adoption of an organization. In this study only use process innovation and product innovation. 
In this organizational study performance measured from a balanced perspective between internal-external refers to the concept of the balanced scorecard [17]. Organizational performance is measured from four perspectives or indicators, namely: Non-financial Perspective, Customer Perspective, Operational Process Perspective, and Learning and Growth Perspective.

\section{Population and Sample}

The population in this study were all employees of XYZ, this study uses analytical methods Partial Least Square based component, the number of samples used unnecessarily large. The sample used can range from 30-100. The unit sample in this study was Puspitek, XYZ Center, Surabaya and Yogyakarta.

\section{The Method of Collecting Data}

The collection of data by using questionnaires. With this method, the respondents are asked some number of questions in the form of a list of sample questions. Respondents are asked to answer questions or provide feedback on the alternative answers that have been provided. The list of questions on the questionnaire study using measurement Likert Scale, take the scale with a range of grades 1 to 5 namely:

\begin{tabular}{cccc}
\hline No. & Notation & Explanation & Score \\
\hline 1. & SD & Strongly Disagree & 1 \\
2. & D & Disagree & 2 \\
3. & Do & Doubtful & 3 \\
4. & S & Agree & 4 \\
5. & SA & Strongly Agree & 5 \\
\hline
\end{tabular}

Collection by direct interview as a means of verifying the information obtained previously. The interview technique used in this research is an indepth interview. The in-depth interview is the process of obtaining information for the purpose of research by means of question and answer while staring.

\section{Statistics Analysis with Partial Least Square}

Data analysis method used in this research is Partial Least Square which is a powerful method of analysis because it does not assume the data must use a certain scale and can use a small sample. Partial Least Square can also be used to confirm the theory. Compared to covariance-based SEM, PLS component bases are able to avoid two big problems faced by covariance-based SEM (CBSEM) that is an inadmissible solution and factor indeterminacy [12]. The hypothesis in this research will be tested by using Partial List Square (PLS), which is based on p-value and then also analyzed the regression coefficients and coefficients of determination. To analyze the data, used Warp PLS 3.0 software.

The path analysis model of all latent variables in the PLS consists of three sets of relationships: (1) inner model that specifies the relationship between the latent variables (structural model); (2) an outer model that specifies the relationship between latent variables and their indicator or manifest variable (measurement model); (3) weight relation in which case values of latent variables can be estimated [14].

Partial Least Square evaluation model is based on predictor measurement having nonparametric properties. The PLS model in which to be evaluated are:

a. The model of measurement or outer model with the reflexive indicator is evaluated with the convergent and discriminant validity of the indicator as well as composite reliability for block indicator. While outer models with formative indicators are evaluated based on substantive content that is comparing the relative weight and see the significance of the weight measure [8].

b. The structural model or inner model is evaluated by looking at the percentage of variance described by looking at the value of $\mathrm{R} 2$ for the latent construct dependent by using the Stone Geisser Q Squares Test [33], [13] and also looking at the magnitude of its structural path coefficients. The stability of this estimate is evaluated using the t-statistic test obtained from the Bootstrapping procedure.

\section{RESULT AND DISCUSSION}

\section{The Direct Influence of Knowledge Manage- ment on Innovation}

The direct influence of Knowledge Management variables on Innovation. The loading value of Knowledge management and Innovation $\geq 0.5$ indicators with the p-value less than $5 \%$ (significant), it means that the measurement of Knowledge management and Innovation construct has fulfilled the convergence validity requirement. The value of Composite Reliability Coefficients and Cronbach's Alpha Coefficients of Knowledge Management and Innovation variables show a value greater than 0.70 which means Knowledge Management and Innovation variables are reliable. Full Colinearity VIF values in Knowledge Management and Innovation variables are less than 3.3 can be 
said that the model is free from problems of vertical, lateral, and common-bias colinearity. The Average Path Coefficient (APC) value is 0.570 and significantly less than 1\%. The Average R-Square (ARS) value is 0.325 and significant at $5 \%$ and the Average Variance Inflation Factor (AVIF) is equal to 1 less than 5 . With Thus, it can be concluded that the goodness of fit model has been fulfilled.

\section{Estimation Results of Path Coefficient and Effect Size}

The resulting path coefficient is positive in the amount of 0.570 with a p-value of less than $1 \%$. This means that Knowledge management has a significant positive effect on innovation that is better then the Innovation Knowledge management is getting better. Knowledge management relationship with the Organization's performance can be seen in the figure below:

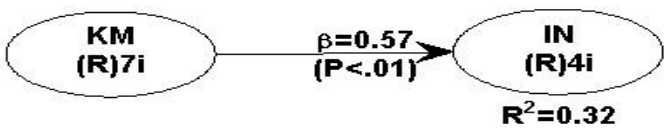

Source: primary data, processed (2017)

Figure 2. Direct Influence of Knowledge Management towards Innovation

While the value of Effect Size generated by 0.325 , this value exceeds 0.15 indicates that Knowledge management has a medium effect on Innovation. The amount of influence on the Innovation Knowledge management can be seen from the R-Squared value Coefficients in the amount of 0.325 which means the influence of the Innovation Knowledge management is $32.5 \%$.

\section{The Direct Influence of Organizational Cul- ture on Innovation}

The value of loading from the Organizational indicator culture and Innovation $\geq 0,5$ with $p$-value value less than 1\% (significant), this means construct measurement Organizational culture and Innovation have fulfilled the convergence validity of reliability test indicate Value Composite Reliability Coefficients and Cronbach's Alpha coefficients value is more than 0.70 , which means variable and Innovation organizational culture is reliable. The Full Colinearity VIF value of Organizational culture and Innovation variables is less than 3.3 so it can be said that the model is free from the problem of vertical, lateral and common method bias collinearity. The Average Path Coefficient (APC) value is 0.688 and significantly less than 1\%. The Average R-Square (ARS) value is 0.473 and significantly less than $1 \%$ and the
Average Variance Inflation Factor (AVIF) is equal to 1 less than 5. Thus, it can be concluded that the goodness of fit model has been fulfilled

\section{Estimation Results of Path Coefficient and Effect Size}

The resulting path coefficient is positive in the amount of 0.688 with a p-value of less than $1 \%$. This means that the organizational culture significant positive effect on innovation that is better than the Organizational Culture of Innovation, the better. The relationship of Culture organization with organizational performance can be seen in the figure below:

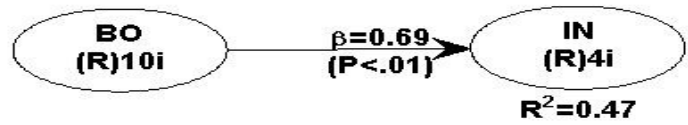

Source: primary data, processed (2017)

Figure 3. Di rect Influence of Organizational Culture towards Innovation

While the value of Size Effect generated at 0.473 , this value exceeds 0.35 indicates that organizational culture has a huge influence on innovation. The amount of influence on the organizational culture of innovation can be seen in the RSquared value Coefficients in the amount of 0.473 which means the influence of organizational culture on innovation amounted to $47.3 \%$.

\section{The Direct Influence of Knowledge Manage- ment on Organization Performance}

Loading value of Knowledge management indicator and organizational performance $\geq 0,5$ with $\mathrm{p}$-value value less than $5 \%$ (significant), this means measurement construct Knowledge management and organizational Performance has fulfilled the convergence validity requirement. The value of Composite Reliability Coefficients and Cronbach's Alpha Coefficients from Knowledge Management variables and organizational Performance shows a value of more than 0.70 which means the Knowledge Management and Organization Performance variables are reliable. Full colinearity VIF on Knowledge management variables and organizational performance of less than 3.3 it can be said that the model is free from problems of vertical, lateral and common method bias collinearity. The Average Path Coefficient (APC) value is 0.476 and significantly less than $5 \%$. Average R-Square (ARS) value is 0.226 and Average Variance Inflation Factor (AVIF) is equal to 1 less than 5. Thus, it can be concluded that goodness of fit model has been fulfilled 


\section{Results of Path Coefficient Estimation and Effect Size}

The resulting path coefficient is positive that is equal to 0.476 with the p-value less than $5 \%$. This means that Knowledge management has a significant positive effect on organizational performance is the better Knowledge management then the better the organization's performance. Relationship Knowledge management with organizational performance can be seen in the following figure:

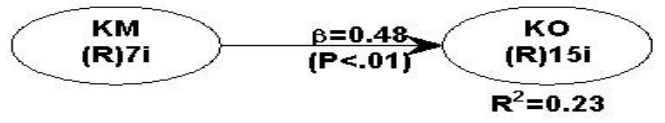

Source: primary data, processed (2017)

Figure 4. The Direct Influence of Knowledge Management on Organization Performance

While the value of Effect Size generated by 0.226 , this value exceeds 0.15 indicates that knowledge management has a medium effect on organizational performance. The amount of influence Knowledge management on organizational performance can be seen from the value of $R$ Squared Coefficients that is equal to 0.23 which means the amount of influence Knowledge management on organizational performance is $23 \%$.

\section{The Direct Influence of Organizational Culture on Organization Performance}

Loading value of organizational culture and organizational performance $\geq 0,50$ with the $p$-value less than 5\% (significant), this means construct Organizational measurement culture and organizational Performance have fulfilled the requirement of convergent validity. The value of Composite Reliability Coefficients and Cronbach's Alpha Coefficients from organizational culture variable and organizational performance shows that the value of more than 0.70 means organizational culture variable and organization performance is reliable. VIF Full Colinearity value on organizational culture variable and organizational performance are less than 3.3 it can be said that the model is free from vertical, lateral and common case bias collinearity problems. Average Path Coefficient (APC) and Average R-Square (ARS). The resulting Average Path Coefficient (APC) is 0.426 and significantly less than 5\%. The Average R-Square (ARS) value is 0.181 and significantly less than 5\%. Average Variance Inflation Factor (AVIF) value is less than 5 Thus, it can be concluded that the goodness of fit model has been fulfilled

\section{Results of Path Coefficient and Effect Size}

The resulting path coefficient is positive in the amount of 0.426 with a p-value of less than $5 \%$ This means Cultural organizations significant positive effect on organizational performance is getting a better culture of the organization, the better organizational performance. The relationship of organizational culture with organizational performance can be seen in the following figure:

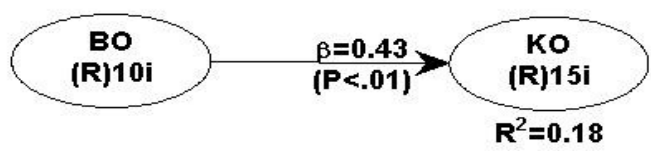

Source: primary data, processed (2017)

Figure 5. The Direct Influence of Organizational Culture on Organization Performance

While the value of Size Effect generated at 0.181 , this value exceeds 0.15 indicates that organizational culture has a medium impact on organizational performance. The magnitude of the influence of organizational culture on organizational performance can be seen from the value of $R$ Squared Coefficients that is equal to 0.18 which means the magnitude influence of organizational culture on organizational performance is equal to $18 \%$.

\section{The Direct Influence of Innovation on Orga- nization Performance}

Loading value of Innovation and Organizational Performance indicator $\geq 0.5$ with $p$-value value less than $1 \%$ (significant), this means that the measurement of Innovation and Performance constructs of the organization has met the requirement of convergent validity. The value of Composite Reliability Coefficients and Cronbach's Alpha Coefficients of the Innovation and Performance organizational variables showed a value greater than 0.70 which means that the Innovation and Performance variables of the organization are reliable. The Full Colinearity VIF value of the Innovation and Organizational Performance variables is less than 3.3 so it can be said that the model is free from vertical, lateral and common method biased collinearity problems. Average Path Coefficient (APC) and Average R-Square (ARS). The Average Path Coefficient (APC) value is 0.330 and significantly less than 1\%. The Average R-Square (ARS) value is 0.109 and the Average Variance Inflation Factor (AVIF) is equal to 1 less than 5. Thus, it can be concluded that goodness of fit model has been fulfilled. 


\section{Estimation Results of Path Coefficient and Effect Size}

The resulting path coefficient was positive amounting to 0.33 with a p-value $>10 \%$ (not significant). This means that innovation does not affect the organization's performance. Relationship Innovation with the performance of the Organization can be seen in the following figure:

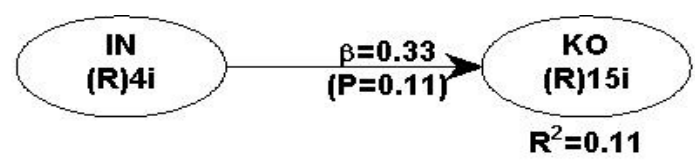

Source: primary data, processed (2017)

Figure 6. The Direct Influence of Innovation on Organization Performance

\section{Indirect Influence Testing}

The indirect effect test is intended to test the relationship of knowledge management with organizational performance through innovation mediation variables, and test the relationship of organizational culture with organizational performance through innovation variable

\section{Knowledge Management has an influence on Organization Performance through Innova- tion Validity, Reliability, Colinearity, and Model Data Compatibility Testing}

The validity, reliability, and compatibility testing uses colinearity data model. The value of loading of knowledge management, innovation and organizational performance indicators is more than 0,50 with the p-value less than $5 \%$ (significant), it means that the measurement of knowledge management, innovation and organizational performance have fulfilled the convergence validity requirement. Convergent validity can also be seen from the AVE value. AVE value of the knowledge management, innovation and organizational performance variable is more than 0,50 , which means that the measurement of knowledge management, innovation and organizational performance has fulfilled the convergence validity criteria.

Reliability test can be seen from the value of Composite Reliability Coefficients and Cronbach's Alpha Coefficients from the variable of knowledge management, innovation and organizational performance. The value of Composite Reliability Coefficients and Cronbach's Alpha Coefficients from the variable of knowledge management, innovation and organizational performance is more than 0.70 , which means that the knowledge management, innovation and organizational performance variables are reliable. For the collinearity test in this research data is free from collinearity problem because the value of full collinearity on the variable of knowledge management, innovation and organizational performance is less than 3.3.

For Model Compatibility test, it can be seen on Average Path Coefficient (APC) and Average RSquare (ARS) value. Average Path Coefficient (APC) value is 0.408 and significantly less than $1 \%$. Average R-Square (ARS) generated at 0.193. Average Variance Inflation Factor (AVIF) value is 1.056 less than 5 . Thus, it can be concluded that the goodness of fit model has been fulfilled.

\section{Estimation Results of Path Coefficient, Effect Size, and R-Squared}

Coefficient Estimation Result of Line, Effect Size and R-Squared. Path coefficient test generates indirect influence Knowledge management variables on organizational performance through innovation is positive. Knowledge management positively significant $1 \%$ influence on innovation, the influence of Knowledge management on organizational performance have positive and significant effect $1 \%$, the influence of innovation on organizational performance has a negative and insignificant effect.

The value of Effect Size between knowledge management and innovation variables is 0.325 , this value is close to 0.35 indicates that knowledge management has a big influence on Inofasi. Effect Size value between knowledge management variable and organizational performance of 0.138 , shows that knowledge management has a medium effect on organizational performance. Values between variables Innovation Effect Size organizational performance of 0.170 , indicating that innovation has a medium impact on the performance of the organization. Variations in the organization's performance can be explained by variations in knowledge management and innovation by $6 \%$, while the innovation variation can be explained by variations in knowledge management by $32 \%$.

Earlier, on the model of the direct effect (4.1.c) indicates that knowledge management influence on the organizational performance of 0.48 and is statistically significant at the $1 \%$ level. This means that knowledge management has a statistically significant effect on the organization's performance, the better the knowledge management the better the organization's performance. The coefficient of determination (R2) indicates that the variance of organizational performance can be explained by the variance of knowledge management of $32 \%$.

The indirect effect model shown in Figure shows that the direct influence of Knowledge Management on organizational performance is 
significant at the level of $1 \%$ with the value of the path coefficient down to 0.42 . Because one of the correlation variable relationships is not significant it is said not as a mediation variable so it is not done testing the influence of innovation mediation variable on the relationship of Knowledge management with Organizational Performance. The sixth hypothesis in this study that states Knowledge management has an influence on Organizational Performance through innovation has not been proven.

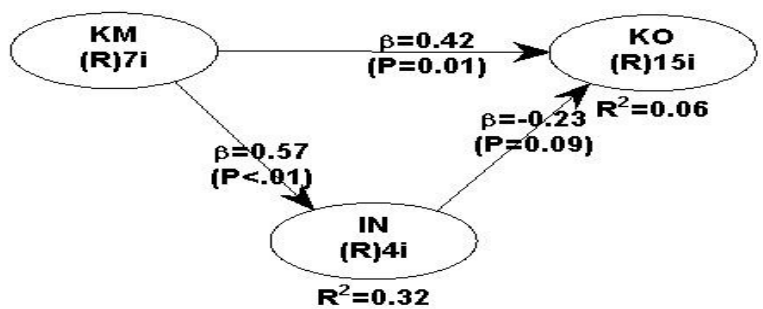

Source: primary data, processed in 2017

Figure 7. Innovation of Relationship-Based Knowledge Management to Organizational Performance

Organizational Culture has an influence on Organizational Performance through Innovation Test Validity, Reliability, Collinearity and Data Model Compatibility

Test results validity, reliability, and compatibility colinearity data model. The loading value of the Bud1 indicator is 5\% (significant), this means that the construct measurement of the organization, innovation and organizational performance has fulfilled the convergence validity requirement.

Reliability test can be seen from the value of Composite Reliability Coefficients and Cronbach's Alpha Coefficients more than 0.70 which means variable Organizational culture, innovation and organizational performance is reliable. The value of full collinearity in each SPK variable is less than 3.3. Which shows free colinearity

Average Path Coefficient (APC) and the average value of R-Square (ARS) .Value Average Path Coefficient (APC) generated by 0.395 and significant at 1\%. Average value of R-Square (ARS) generated by 0,291.Nilai Average Variance Inflation Factor (AVIF) amounted to 1.366 less than 5 . Thus, it can be concluded that the goodness of fit of models has been fulfilled.

\section{Estimation Results of Path Coefficient, Effect Size and R-Squared}

Results of Path Coefficient Estimation, Effect Size and R-Squared.Koefisien path resulting from testing the indirect effect of variables Organizational culture on organizational performance through innovation is positive. Organizational culture has a significant positive effect of $1 \%$ on innovation, the influence of organizational culture on organizational performance has positive but not significant $1 \%$, and the effect of innovation on organizational performance has a negative and insignificant effect.

Effect Size value between organizational culture variables with the innovation of 0.473 , this value is close to 0.35 indicates that organizational culture has a considerable influence on Innovation. Effect Size value between organizational culture variables and organizational performance of 0.189 , indicates that knowledge management has a medium effect on organizational performance. Effect Size value between Innovation variables with the organizational performance of 0.049 , indicating that innovation has a low effect on organizational performance. Variations in organizational performance can be explained by organizational culture and innovation variations of $11 \%$, while the variation of innovation can be explained by a variety of organizational culture by $32 \%$.

Earlier, on the model of a direct effect on (4.1.d) indicated that organizational culture affected the organizational performance of 0.43 and was statistically significant at the $1 \%$ level. This means that the organizational culture has a statistically significant effect on organizational performance that is the better the organizational culture the better the organization's performance. The coefficient of determination (R2) indicates that the variance of organizational performance can be explained by the knowledge management variance of $18 \%$.

In the indirect effect model shown in Figure shows that the direct influence of Knowledge Management on organizational performance is significant at the level of $1 \%$ with the value of the path coefficient down to 035 . Because one of the correlation variable relationships is not significant it is said not as a mediation variable so it does not test the influence of mediation variable of innovation to organizational culture relationship with Organizational Performance. The seventh hypothesis in this study which states that organizational culture has an influence on organizational performance through innovation is not proven.

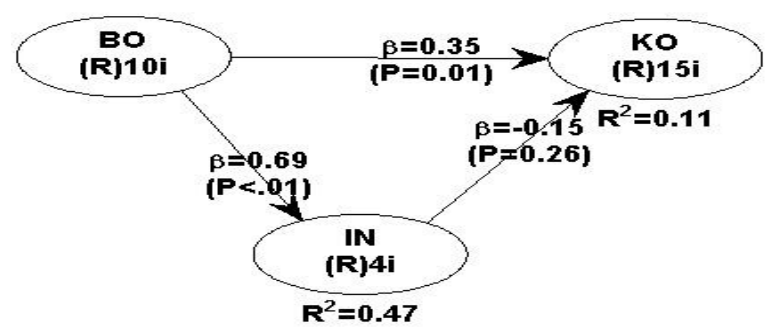

Source: primary data, processed in 2017

Figure 8. Innovation Mediating the Relationship of Organizational Culture to Organizational Performance 


\section{Discussion}

The results of this study indicate empirical support of a positive and significant relationship between knowledge management variables on organizational performance, this is in accordance with research [5] stating that Knowledge management has emerged as a source of sustainable competitive advantage. Knowledge management is one of the management tools that can be used to support the achievement of organizational goals and demonstrate competitive advantage so as to create good organizational performance [20]. In addition, the results of the study also showed a positive influence between organizational cultures on organizational performance, the results of this study support the study [40].

Further research results also show that the positive effect of knowledge management on the performance of the organization it supports the statement from [23] stating that the Innovation related to the knowledge that can be used to create new products or processes and services in order to improve competitive advantage and meet the needs ever-changing customers. The results also showed that organizational culture has a positive effect on innovation. This study supports research [19] which states that for the success of innovation and adopt technology advances, companies must be able to meet the requirements in terms of the behavior of internal and external relations at the same time.

This study does not support the research of [4] which shows a positive relationship between business performance and innovation [35]. [39] Empirical research examines the relationship of knowledge management to organizational performance through innovation and examines the relationship between organizational culture on organizational performance through innovation. This research does not support the research of [18], [38] which states that knowledge management has an effect on organizational performance both directly and indirectly through innovation Empirically this research does not support [16], [21] which argued that organizational culture promotes innovation and organizational performance, but empirically this research supports the research of [25]; [37] which states that knowledge management has an effect on innovation but innovation has no pen attached to organizational performance and research [35] stating that organizational culture chews immediate effect on organizational performance but does not have an indirect effect on organizational performance through innovation.

To find out why the variable innovation does not affect the performance, the researchers con- ducted interviews with an informant at XYZ, the interview was conducted as directed and depth. The results of these interviews are as follows:

"Perception of innovation by the State as a civil apparatus is different waiters' domain management, innovation emerge for their freedom of thought and action but because the government already established indicators and targets to be achieved then the resulting gaps in innovation".

"Because it was thought that the authority of the authority in line with the authority and direction of innovation, then innovation is often dependent on the individual who has the authority that is willing to turn innovation itself".

In XYZ knowledge management system is less than optimal, it is asserted in the statement of informants is "supposed knowledge possessed by a decision maker needs to be bridged by the frequent conduct meetings (the transfer of knowledge) with the researchers, this is less to do in XYZ, groove transfer knowledge should be from top to bottom, but what happens on the field is instead"

Cultural organizations in XYZ itself does not support innovation, according to the informant due to the vision and mission of XYZ abstract so it's hard to be an indicator of the success of the organization's performance, should as institutions that produce innovation in the field of science and technology, the output to be achieved should be clear, hope of informants, "the development of innovation needs the support of freedom of thought and legal protection as well as incentives for the development of innovation in XYZ"

\section{CONCLUSION AND LIMITATION}

The results showed that (1) knowledge management influence on innovation, (2) organizational culture influence on innovation, (3) knowledge management influence on organizational performance; (4) The effect on the organizational culture on organizational performance; (5) innovation does not affect the performance of the organization; (6) innovation does not mediate the relationship of knowledge management to organizational performance; (5) innovation does not mediate the relationship of organizational culture on organizational performance.

There are several limitations of this study can be taken into consideration for future research. First, the small sample size may reduce the strength of statistical testing. In addition, the study sample is just from XYZ so the findings of this study cannot be generalized to other public sector organizations. Future research may consider the use of larger sample sizes and from public sector organizations other than XYZ. 


\section{REFERENCES}

[1] Acar, A. Z., and P. Acar. 2012. The Effects of Organizational Culture and Innovativeness on Business Performance in Healthcare Industry. Procedia - Social and Behavioral Sciences, 58, 683-692.

[2] Agbim, K.C., G.O. Oriarewo, dan A.E. Omattah. 2013. An Exploratory Study of the Relationship between Innovation and Change Management. International Journal of Scientific and Research Publications, 3(6), June 2013.

[3] Ahmad, M. S. 2012. Impact of Organizational Culture on Performance Management Practices in Pakistan. Business Intelligence Journal, 5(1), 50-55.

[4] Al-Ansari, Y., S. Pervan, and J. Xu. 2013. Innovation and Business Performance of SMEs: The Case of Dubai. Education, Business and Society: Contemporary Middle Eastern Issues, 6(3/4), 162-180.

[5] Barney, J. 1991. Firm Resources and Sustained Competitive Advantage. Journal of Management, 17(1), 99-120.

[6] Barney, J. B. 1986. Organizational Culture: Can It Be a Source of Sustained Competitive Advantage? Academy of Management Review, 11(3), 656-665.

[7] Carolina López-Nicolás, Á.L. Merõ no-Cerdán, 2011. Strategic knowledge management, innovation and performance, International Journal of Information Management. 31: 502-509

[8] Chin, W. W. 1998. The Partial Least Squares Approach to Structural Equation Modeling. Modern Methods for Business Research, 295(2), 295-336.

[9] Damanpour, F. 1991. Organizational Innovation: A Meta-Analysis of Effects of Determinants and Moderators. Academy of Management Journal, 34(3).

[10] Damanpour, F., dan M. Schneider. 2009. Characteristics of Innovation and Innovation Adoption in Public Organizations: Assessing the Role of Managers. Journal of Public Administration Research and Theory, 19(3), 495-522.

[11] De Keith Davis, A., and J. W. Newstrom. 1985. Human Behavior at Work: Organizational Behavior, McGraw-Hill, Nueva York.

[12] Fornell, Claes dan F.L. Bookstein (1982). Two structural Equation Models: LISREL and PLS Applied to Consumer Exit-Voice Theory. Journal of Marketing Research, XIX (November), 440-452

[13] Geisser, Seymour 1975. The Predictive Sample Reuse Method with Applications. Journal of the American Statistical Association, 70 (June), 320-328

[14] Ghozali, I. 2008. Structural Equation Modeling: Alternative Method with Partial Least Square (Pls). Semarang, Indonesia.

[15] Honeycutt, J. 2000. Knowledge Management Strategies: Mapping Your Organization's Success in Today's Competitive Marketplace: Little, Brown \& Co. Inc

[16] Hogan, S. J., dan L. V. Coote. 2014. Organizational Culture, Innovation, and Performance: A Test of Schein's Model. Journal of Business Research, 67(8), 1609-1621.

[17] Kaplan, R. S., and D. P. Norton. 1996. The Balanced Scorecard: Translating Strategy into Action. Harvard Business Press.

[18] López-Nicolás, C., dan Á. L. Meroño-Cerdán. 2011. Strategic Knowledge management, Innovation and Performance. International Journal of Information Management, 31(6), 502-509.

[19] Martins, E., dan F. Terblanche. 2003. Building Organisational Culture That Stimulates Creativity and Innovation. European Journal of Innovation Management, 6(1), 64-74.

[20] Megantoro, R. G., M. Miyasto, dan M. Rahardjo. 2014. Pengaruh Budaya Organisasi Terhadap Kinerja Organisasi dengan Knowledge Management Sebagai Variabel Mediating (Studi Empiris pada Badan Pengawasan Keuangan dan Pembangunan (Bpkp)). Diponegoro University.

[21] Naranjo-Valencia, J. C., D. Jiménez-Jiménez, dan R. Sanz-Valle. 2016. Studying the Links between Organizational Culture, Innovation, and Performance in Spanish Companies. Revista Latinoamericana de Psicología, 48(1), 30-41.

[22] Nielsen, P., P. Rasmussen, Y.-C. Hsiao, C.-J. Chen, dan S.-C. Chang. 2011. Knowledge management Capacity and Organizational Performance: The Social Interaction View. International Journal of Manpower, 32(5/6), 645-660.

[23] Nonaka, I., dan H. Takeuchi. 1995. The Knowledge Creation Company: How Japanese Companies Create the Dynamics of Innovation. Oxford University Press. New York, USA, 304.

[24] Nothnagel, K. 2008. Empirical Research within Resource-Based Theory: A MetaAnalysis of the Central Propositions: Springer Science \& Business Media.

[25] Noviyanti, T., dan A. D. Mulyanto. 2015. Pengaruh Knowledge Management Terhadap Inovasi, Implementasi Strategi Dan Kinerja Organisasi (Studi Pada Rs Lavalette Malang). Jurnal Ekonomi Bisnis, 20(1). 
[26] Olanipekun, A., I. Aje, dan J. Abiola-Falemu. 2013. Effects of Organisational Culture on the Performance of Quantity Surveying Firms in Nigeria. International Journal of Humanities and Social Science, 3(5), 206-215.

[27] Robbins, S. P., dan T. A. Judge. 2002. Perilaku Organisasi. Buku 2, Jakarta: Salemba Empat.

[28] Robbins, S. P., dan T. A. Judge. 2006. Perilaku Organisasi. Edisi Bahasa Indonesia. Jakarta. PT. Indeks Kelompok Gramedia.

[29] Salaman, Graeme dan J. Storey. 2002. Manager's Theories About the Process of Innovation. Journal of Management Studies, 39(2) March 2002.

[30] Scholz, C. (1987). Corporate culture and strategy_The problem of strategic fit. Long Range Planning, 20(4), 78-87.

[31] Schwartz, H., dan S. M. Davis. 1981. Matching Corporate Culture and Business Strategy. Organizational Dynamics, 10(1), 30-48.

[32] Shahzad, F., R. A. Luqman, A. R. Khan, dan L. Shabbir. 2012. Impact of Organizational Culture on Organizational Performance: An Overview. Interdisciplinary Journal of Contemporary Research in Business, 3(9), 975.

[33] Stone, M. 1974. Cross-Validatory Choice and Assessment of Statistical Predictions. Journal of the Royal Statistical Society, Series B (Methodological), 36(2), 111-147.

[34] Uriarte A. Filemon, Introduction to Knowledge Management, ASEAN Foundation, 2008, Jakarta, Indonesia.
[35] Uzkurt, C., R. Kumar, H. Semih Kimzan, and G. Eminoglu. 2013. Role of Innovation in the Relationship between Organizational Culture and Firm Performance: A Study of the Banking Sector in Turkey. European Journal of innovation management, 16(1), 92-117.

[36] Yeşil, S., dan A. Kaya. 2012. The Role of Organizational Culture in Innovation Capability: An Empirical Study. International Journal of Information Technology and Business Management, 6(1), 11-25.

[37] Yeşil, S., Büyükbeşe, Koska, A. 2013. Exploring The Link Between Knowlegde Sharing Enablers, Innovation Capability and Innovation Performance. International Journal of Management, 17(4).

[38] Yousif Al-Hakim, L. A., and S. Hassan. 2013. Knowledge Management Strategies, Innovation, and Organisational Performance: An Empirical Study of the Iraqi Mts. Journal of Advances in Management Research, 10(1), 5871.

[39] Zehir, C., E. Altindag, dan A. Z. Acar. 2011. The Effects of Relationship Orientation through Innovation Orientation on Firm Performance: An Empirical Study on Turkish FamilyOwned Firms. Procedia-Social and Behavioral Sciences, 24, 896-908.

[40] Zheng, W., B. Yang, dan G. N. McLean. 2010. Linking Organizational Culture, Structure, Strategy, and Organizational Effectiveness: Mediating Role of Knowledge Management. Journal of Business Research, 63(7), 763-771. 